\title{
Pengembangan Media Pembelajaran Berbasis E-Bookstory untuk Meningkatkan Literasi Membaca Siswa Sekolah Dasar
}

\author{
Desy Getri Sari Gogahu1, Tego Prasetyo \\ Universitas Kristen Satya Wacana, Jawa Tengah, Indonesia ${ }^{1,2}$ \\ E-mail: 292016601@ @ student.uksw.edu ${ }^{1}$, desygogahu@gmail.com² , tego.prasetyo@uksw.edu ${ }^{3}$
}

\begin{abstract}
Abstrak
Penelitian ini bertujuan untuk mengetahui produk yang dikembangkan efektif untuk digunakan dalam pembelajaran literasi membaca. Penelitian ini menggunakan jenis penelitian dan pengembangan (R\&D), dengan prosedur pengembangan oleh Sukamadinata yang dikonversi dan dimodifikasi dengan model pengembangan 4D atau Four D Models (Define, Design, Development, dan Dissminate). Pada penelitian ini peneliti hanya sampai pada prosedur pengembangan dan tidak melakukan uji coba secara langsung (Dissminate) dikarenakan kondisi darurat kesahatan akibat dampak dari covid-19. Teknik pengumpulan data yang dilakukan peneliti yaitu melalui uji pakar. Uji pakar yang digunakan adalah uji pakar materi dan uji pakar media. Data hasil validasi produk oleh pakar materi dan pakar media, akan dianalisis menggunakan teknik deskriptif persentase dan kategori untuk menunjukkan keefektifan/kelayakan media. Hasil pengembangan produk yang dilakukan peneliti melalui validasi ahli materi memperoleh skor 49 dengan persentase $81 \%$ sehingga dikategorikan sangat tinggi dan layak digunakan. Hasil validasi ahli media 1 memperoleh skor 47 dengan persentase $67 \%$, dan hasil validasi media 2 memperoleh skor 43 dengan persentase $61 \%$ sehingga dikategorikan tinggi dan layak untuk digunakan.
\end{abstract}

Kata kunci: $R \& D, 4 D$ (Define, Design, Development, Dissminate)

\begin{abstract}
This study aims to find out the prodects develiped are effective for use in reading literacy learning. This study uses a type of research and development $(R \& D)$, with development procedures by Sukmadinata tha are converted and modified with 4D or Four D Models development models (Define, Design, Development, Dissminate). In this study, researchers only arrived at the development procedure and did not conduct a trial directly (Dissminate) due to a health emergency due to the impact of covid-19. Data collection technques conducted by researchers is through expert testing. The exepert test used was material expert test and media expert test. Data validation results by material experts and media experts, will be analyzed using descriptive techniques of percentages and categories to show the effectiveness/feasibility of media. The results of product development conducted by researchers through the validation of material experts obtained a score of 49 with a percentage of $81 \%$ so that is categorized very high and suitable for use. The results of the validation of media experts 1 obtained a score of 47 with a percentage of $67 \%$ and the results of the validation of media 2 earned a score of 43 with a percentage of $61 \%$ so that is was categorized high and suirable for use.
\end{abstract}

Keywords: $R \& D, 4 D$ (Define,Design, Development, Dissminate)

Copyright (c) 2020 Desy Getri Sari Gogahu, Tego Prasetyo

$\triangle$ Corresponding author :

Address : Universitas Kristen Satya Wacana

Email : 292016601@student.uksw.edu

Phone : -

DOI : https://doi.org/10.31004/basicedu.v4i4.493
ISSN 2580-3735 (Media Cetak)

ISSN 2580-1147 (Media Online) 
1005 Pengembangan Media Pembelajaran Berbasis E-Bookstory untuk Meningkatkan Literasi Membaca Siswa Sekolah Dasar - Desy Getri Sari Gogahu, Tego Prasetyo.

DOI: https://doi.org/10.31004/basicedu.v4i4.493

\section{PENDAHULUAN}

Literasi membaca merupakan kemampuan yang berkaitan dengan kegiatan membaca, berpikir, dan menulis yang bertujuan untuk meningkatkan kemampuan memahami informasi secara kritis, kreatif, dan reflektif. Dalam undang-undang No.3 Tahun 2017 tentang Sistem Perbukuan, dinyatakan bahwa literasi merupakan kemampuan untuk memaknai informasi secara kritis sehingga setiap orang dapat mengakses ilmu pengetahuan dan teknologi sebagai upaya dalam meningkatkan kualitas hidupnya. Menurut Satgas (GLS, 2018) literasi dipahami sebagai ilmu pengetahuan dan teknologi harus yang dipahami oleh masyarakat, bukan hanya sekedar kebutuhan semata namun juga untuk dapat meningkatkan kualitas hidup seseorang dalam masa yang akan datang.

Peraturan Menteri Pendidikan dan Kebudayaan Nomor 23 Tahun 2015 tentang Penumbuhan Budi Pekerti. Permendikbud tersebut bertujuan untuk mencetak siswa yang memiliki budi pekerti yang luhur melalui berbagai pembiasaan. Salah satu nilai yang ingin dicapai adalah siswa yang berbudaya literasi. Nilai ini dicapai dengan memberikan pembiasaan membaca buku bacaan selama 15 menit sebelum pembelajaran. Setiap anak di sekolah diwajibkan membaca buku-buku bacaan cerita lokal dan cerita rakyat yang memiliki kearifan lokal dalam bacaannya. Sekolah Dasar merupakan masa anakanak pada usia perkembangan sehingga penting untuk menanamkan nilai-nilai budi pekerti luhur. Leterasi bisa dijadikan sebagai dasar pembelajaran di sekolah.
Menurut Suyono (2017: 116-123) literasi bisa digunakan sebagai dasar pengembangan pembelajaran efektif di sekolah yang dapat membuat siswa terampil dalam mencari dan mengolah informasi yang dibutuhkan dalam kehidupan berbasis ilmu pengetahuan pada abad ke21, namun tingkat literasi siswa Indonesia tergolong rendah dibandingkan dengan negara lain, dibuktikan dalam Laporan studi IAEA (International Achivement Education Assocation) di Asia Timur, literasi membaca terendah anakanak, dipegang oleh negara Indonesia dengan skor 51,7 dibawah negara Filipina yang memiliki skor 52,6 serta negara Thailand dengan skor 65,1 Singapura skor 74,0 dan Hongkong memiliki skor tertinggi yaitu 75,5. Hasil dari laporan ini, menunjukkan dan membuktikan bahwa Indonesia masih sangat kurang dalam hal membaca.

Menurut data yang kedua di peroleh dari World's Most Literate Nations, dikumpulkan oleh Central Connecticut State University tahun 2016, Indonesia berada di posisi kedua terbawah, peringkat literasi dari 61 negara yang telah diteliti (Agoestyowati, 2017). Indonesia hanya sedikit lebih baik dari negara Bostwana, negara di kawasan selatan Afrika. Data tersebut memunjukkan bawa kondisi literasi membaca bangsa Indonesia memang cukup memprihatinkan. Perlu ada upaya dalam menangani hal tersebut termasuk penyediaan bahan bacaan untuk membaca dalam pembelajaran literasi membaca. Baleiro (2011: 17) menyatakan bahwa definisi literasi harus memperhitungkan sifat sebuah konsep yang mengkaji tentang keberadaan, kontekstual, akibatnya, relatif, dan terikat budaya. Dalam literasi membaca terdapat empat kajian 
1006 Pengembangan Media Pembelajaran Berbasis E-Bookstory untuk Meningkatkan Literasi Membaca Siswa Sekolah Dasar - Desy Getri Sari Gogahu, Tego Prasetyo.

DOI: https://doi.org/10.31004/basicedu.v4i4.493

utama, yaitu: 1) penerapan latihan dan penetapan bacaan, 2) keterampilan membaca, 3) teks yang digunakan dalam membaca, 4) proses membaca, (UNESCO, 2009).

Kenyataannya bahwa untuk literasi membaca siswa sekolah dasar hanya dilakukan pada bukubuku pelajaran pokok yang digunakan di sekolah. Hal ini yang membuat siswa kurang suka membaca, karena buku bacaannya kurang menarik, selain itu juga isi bacaan dengan tulisan tanpa gambar dan warna yang membuat siswa tidak tertarik dan buku yang dibaca atau digunakan hanya itu-itu saja, sehingga siswa cepat bosan. Melihat kenyataan tersebut, supaya membaca menjadi suatu hobi siswa dimana bukan hanya sekedar tugas semata, maka perlu adanya tindakan yang membiasakan siswa mulai dari sekarang membaca buku dan menjadikan literasi membaca hal yang menyenangkan (Dalman, 2013). Oleh karena itu, guru memiliki peran yang sangat menentukan kuantitas dan kualitas pembelajaran yang pada akhirnya berperan dalam meningkatkan mutu pedidikan nasional.

Buku merupakan sumber dari terlaksananya literasi yang berfungsi sebagai jendela dunia. Buku bacaan siswa SD tentu saja harus berbeda dari buku bacaan yang lainnya, dimana buku bacaan SD banyak menyajikan teks, warna, dan gambar yang menarik sehingga dapat merangsang minat membaca siswa dalam belajar.

Seiring perkembangan zaman yang terjadi dalam kehidupan masyarakat, menjadikan SDM semakin berubah dengan mengikuti kecanggihan teknologi tersebar dengan cepat dan sangat luas, yang dapat dibuktikan dengan adanya media IT (Informasi dan Teknologi) yang dapat memenuhi kebutuhan hidup masyarakat. Pesatnya perkembangan yang terjadi juga dapat dimanfaatkan oleh guru dalam mendidik siswanya. Pendidikan yang ada di Indonesia juga sudah termasuk dalam rancangan yang berkemajuan. Media-media pembelajaran berbasis IT ini dapat digunakan dalam proses belajar mengajar, misalnya penggunaan internet. Semua guru harus bisa memanfaatkan teknologi sehingga mudah mengakses informasi dengan cepat tanpa menunggu lama. Cepatnya perubahan zaman yang serba mudah dan praktis ini ternyata bisa menggeser pola pikir malas membaca berubah menjadi minat baca. Siswa cenderung lebih menyukai buku dengan animasi gerak dan berwarna, sehingga dapat membuat siswa suka membaca buku dalam bentuk file dari pada baca buku cetak.

Penelitian yang dilakukan oleh Martinez dan Lopes-Rio (2015: 178) mengungkapkan bahwa munculnya teknologi berbasis internet mengakibatkan adanya cara membaca yang baru. Salah satunya merupakan munculnya fitur E-Book atau buku digital. Adanya E-Book bisa membuat pengguna teknologi mendownload sebuah buku yang kemudian disimpan pada perangkat teknologi yang dimiliki. Penelitian yang terkait penggunaan buku bacaan digital juga pernah dilakukan oleh (Dizon, 2014) yang meneliti pengaruh penggunaan buku bacaan digital serta kegiatan membaca digital, terhadap motivasi membaca siswa di sekolah dasar. Dari hasil penelitian yang diperoleh menunjukkan bahwa peserta didik yang membaca buku digital memiliki tingkat motivasi membaca yang lebih tinggi dari pada peserta didik yang tidak mengikuti kegiatan membaca. Berdasarkan hasil penelitian di 
1007 Pengembangan Media Pembelajaran Berbasis E-Bookstory untuk Meningkatkan Literasi Membaca Siswa Sekolah Dasar - Desy Getri Sari Gogahu, Tego Prasetyo.

DOI: https://doi.org/10.31004/basicedu.v4i4.493

atas, menunjukan bahwa dengan penggunaan teks bacaan digital dapat memberikan pengaruh positif maupun negatif kepada seseorang khususnya dalam minat terhadap membaca buku.

E-bookstory adalah buku berbasis digital yang dikenal dapat mengedukasi siswa. Dengan memanfaatkan teknologi yang kian semakin dekat dengan kehidupan siswa E-bookstory dapat dikemas secara modern dan lebih interaktif yang memiliki desain visual, storyline, serta fitur integratif yang diminati oleh siswa, yang disajikan dalam bentuk digital, sehingga bisa di nikmati siswa dengan berbagai cara media elektronik seperti komputer, smartphone, dan tablet. Pengembangan media E-bookstory didesain menekankan pada penyajian uraian cerita yang mendukung pemahaman siswa terhadap materi pembelajaran tematik integratif, sesuai karakteristik kurikulum 2013, sehingga tema-tema yang digunakan pada uraian cerita sehingga proses pembelajaran yang terjadi dapat mendukung siswa dalam memahami dan memaknai materi pembelajaran. Menurut (Smeets dan Bush, 2012) mengatakan bahwa penggunaan E-bookstory memberikan manfaat kepada pada siswa yaitu dapat membantu siswa belajar tentang kosakata. Moody juga menemukan bahwa penggunaan E-bookstory dapat mendorong kemampuan siswa dalam memahami sebuah cerita. Jadi dapat di simpulkan bahwa E-bookstory merupakan buku cerita digital yang dapat membantu siswa siswa dalam belajar kosakata dan mendorong siwa memahami isi dalam cerita. Penggunaan E-bookstory masih jarang ditemukan atau gunakan di sekolah, siswa masih cenderung membaca menggunakan buku manual atau buku cetak, dimana dalam penggunaan buku manual harus menyediakan tempat buku (rak buku), susah dibawa kemana, dan jika sering dibaca maka buku bisa cepat rusak.

Berdasarkan kondisi tersebut, maka penulis tertarik ingin membuat sebuah media yang namanya E-bookstory untuk meningkatkan literasi membaca siswa. Penulis mengembangkan media pembelajaran berbasis E-bookstory ini, karena penulis melihat bahwa E-bookstory mememudahkan proses penyebaran informasi dan juga membantu proses belajar mengajar, serta praktis dan mudah di bawa kemana-mana. Tujuan penggunaan E-Bookstory ada tiga yaitu 1) sebagai sarana dalam pembelajaran, 2) mempermudah guru dan siswa dalam proses pembelajaran, 3) guru dapat memberi materi pembelajaran walau guru sedang tugas diluar (Haris, 2011). Media E-Bookstory memberikan banyak manfaat, yaitu: 1) anak termotivasi untuk belajar membaca lebih cepat, 2) menumbuhkan rasa percaya pada diri anak karena anak telah merasa sukses menjadi pembaca pemula, 3) anak dapat belajar dengan cara yang menyenangkan, 4) mendorong anak untuk lebih menyukai cerita dengan tema dan cerita yang berbeda, 5) secara perlahan menumbuhkan kebiasaan anak untuk dapat membaca cerita secara mandiri (Shofaussamawati, 2016).

Kelebihan menggunakan E-Bookstory adalah, 1) biaya yang digunakan relatif murah, 2) sangat mudah diakses, 3) anti rusak, 4) mudah dibawah kemana-kemana, 5) dapat menghemat waktu (Khalid \& Adeel, 2014). Selain memiliki kelebihan, E-Bookstory juga memiliki kelemahan. Kelemahan E-Bookstory yaitu: 1) pengguna 
1008 Pengembangan Media Pembelajaran Berbasis E-Bookstory untuk Meningkatkan Literasi Membaca Siswa Sekolah Dasar - Desy Getri Sari Gogahu, Tego Prasetyo.

DOI: https://doi.org/10.31004/basicedu.v4i4.493

diharuskan memiliki ruangan yang cukup pada sebuah media elektronik untuk dapat menyimpan file E-Bookstory, 2) tidak semua media elektronik dapat menyimpan E-Bookstory tetapi hanya media elektronik yang sudah berkemajuan dan layak untuk bisa menyimpan dan menggunakan E-Bookstory, 3) masalah teknologi yang muncul dengan menavigasi buku elektronik. Format security ebook, karena digital bisa dibongkar oleh para hacker, 4) untuk mengakses E-Bookstory harus menggunakan HP/Laptop/Komputer yang sudah terhubung dengan koneksi internet (Haris, 2011).

Media merupakan alat saluran komunikasi. Media berasal dari bahasa Latin dan merupakan bentuk jamak dari kata "medium" yang secara harfiah berarti "perantara" atau pengantar, Heinich (dalam Rusman, 2012) Asosiasi Pendidikan Nasional (National Education Association/ NEA) mengartikan bahwa media sebagai segala bentuk dan saluran yang dapat di pakai orang untuk menyalurkan pesan/informasi, Sadiman dkk, (dalam Rusman, 2012) Media pembelajaran yaitu alat atau sarana yang digunakan guru sebagai perantara dalam menjelaskan pesan atau informasi dari sebuah tema pembelajaran yang diberikan kepada siswa. Breidle dan Rossi dalam (Sanjaya, 2012) mengatakan bahwa media pembelajaran merupakan semua alat dan bahan yang bisa digunakan untuk mencapai tujuan pendidikan, media yang dimaksud berupa radio, televisi, buku, koran, majalah, dan sebagainya. Sedangkan menurut (Yaumi, 2012) media pembelajaran adalah peralatan yang menyediakan lingkungan belajar yang kaya dengan dorongan atau rangsangan (contoh video, teks, benda asli, dan multimedia).
Kesimpulan yang dapat ditarik dari pendapat di atas adalah segala sesuatu yang dapat digunakan untuk menyampaikan pesan dari pemberi pesan ke penerima pesan untuk menarik minat, perhatian, pikiran serta perasaan siswa selama proses pembelajaran berlangsung di kelas untuk mencapai tujuan belajar di sebut dengan media pembelajaran

\section{METODE}

Jenis penelitian yang digunakan adalah jenis penelitian Research and Development (R\&D) atau Penelitian dan Pengembangan. R\&D merupakan sebuah strategi atau metode penelitian yang cukup ampuh untuk memperbaiki praktik (Sukmadinata, 2017). Langkah-langkah penelitian menurut (Sukmadinata dkk, 2017) terdiri atas tiga tahap. 1) studi pendahuluan yang meliputi studi literatur, studi lapangan, dan penyusunan draf awal produk, 2) pengembangan, yang terdiri atas uji coba terbatas dan uji coba luas, 3) pengujian, yang terdiri atas pre-test, perlakuan, dan post-test. Dalam penelitian ini peneliti mengunakan prosedur penelitian yang diadaptasi dari (Sukmadinata, 2017) yang dapat dilihat pada gambar 1 dibawah ini:

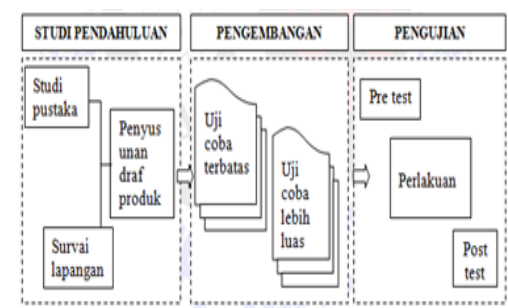

Gambar 1. Langkah-langkah Penelitian dan Pengembangan Menurut Sukmadinata.

Prosedur penelitian di atas dapat lebih efesien dilaksanakan apabila terdapat model pengembangan. Model pengembangan yang 

Siswa Sekolah Dasar - Desy Getri Sari Gogahu, Tego Prasetyo.

DOI: https://doi.org/10.31004/basicedu.v4i4.493

digunakan pada R\&D ini ialah model 4D atau Four D Models. Tahapan model pengembangan ini terdiri dari Define (Pendefinisian), Design (Perancangan), Development (Pengembangan, Disseminate (Penyebaran). Desain pengembangan yang digunakan dalam penelitian ini adalah prosedur penelitian pengembangan menurut Sukmadinata dengan menggunakan model pengembangan 4D yang telah di konversikan dan dimodifikasi seperti pada Gambar 2 berikut ini.

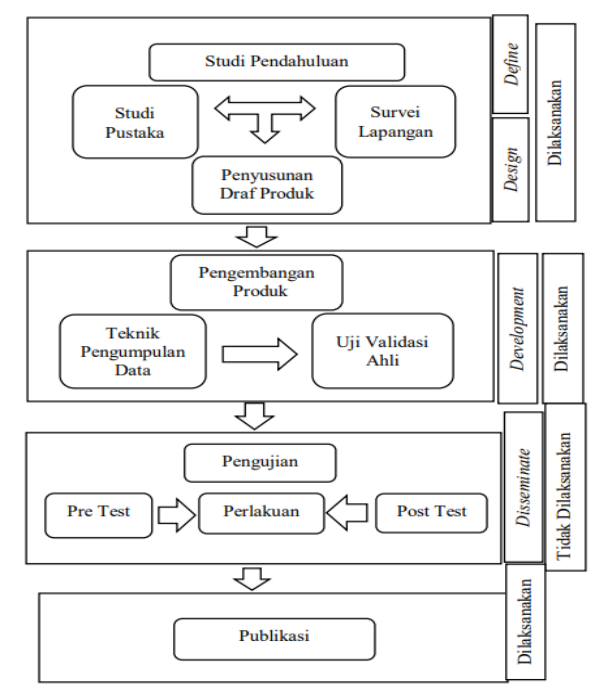

Gambar 2. Modifikasi Prosedur Penelitian Pengembangan Media Pembelajaran Berbasis $E$ Bookstory

\section{A. Tahap Studi Pendahuluan}

Tahap studi pendahuluan merupakan prosedur yang dilakukan pertama kali dalam penelitian R\&D. Tahap ini dilakukan dengan mendeskripsikan pengembangan media pembelajaran berbasis E-Bookstory untuk meningkat literasi membaca siswa kelas $5 \mathrm{SD}$.

\section{a. Studi Pustaka}

Studi pustaka yang dilakukan oleh peneliti yaitu melalui jurnal, buku-buku yang dipilih, artikel, dan sumber-sumber lain yang relevan. Studi pustaka ini dilakukan agar peneliti dapat memahami setiap fenomena dari variabel penelitian yaitu media pembelajaran berbasis $E$ Bookstory untuk meningkatkan literasi membaca siswa kelas $5 \mathrm{SD}$.

\section{b. Survei Lapangan}

Survei lapangan dilakukan untuk memperoleh data-data dalam perencanaan dan pelaksanaan kegiatan pembelajaran. Survei lapangan juga dilakukan agar peneliti mendapatkan informasi mengenai kebutuhan pengembangan produk media. Sumber data yang dapat dikumpulkan meliputi RPP, media pembelajaran atau bahan ajar yang digunakan untuk membaca, dan kondisi dalam kegiatan proses pembelajaran disekolah.

\section{c. Penyusunan Draf Produk Awal}

Penyusunan draf produk awal yang dilakukan mengacu pada hasil studi pustaka dan studi lapangan. Peneliti membuat media pembelajaran E-Bookstory untuk meningkatkan literasi membaca siswa dengan langkah-langkah sebagai berikut:

1. Menentukan KD (Kompetensi Dasar)

Media E-Bookstory dalam penelitian ini merupakan buku elektronik yang berisi gambar animasi dan teks yang dibuat semenarik mungkin. Produk E-Bookstory dikembangkan disesuaikan dengan materi tematik pada buku guru dan buku siswa. Materi dalam media E-Bookstory ini merupakan tema Ekosistem, dengan subtema Komponen Ekosistem, Pembelajaran ke-1 Kompetensi Dasar Bahasa Indonesia : 3.7 

Siswa Sekolah Dasar - Desy Getri Sari Gogahu, Tego Prasetyo.

DOI: https://doi.org/10.31004/basicedu.v4i4.493

mengurai konsep-konsep yang saling berkaitan pada teks nonfiksi, 4.7 menyajikan konsep-konsep yang saling berkaitan pada teks nonfiksi kedalam tulisan dengan bahasa sendiri. Kompetensi Dasar IPA, 3.5 menganalisis hubungan antar komponen ekosistem dan jarring-jaring makanan di lingkungan sekitar, dan 4.5 membuat karya tentang konsep jaring-jaring makanan dalam suatu ekosistem. Desain Media E-Bookstory dibuat menggunakan aplikasi buku digital yang didesain menarik dari cover dan isinya. Animasi dan teks bacaan disesuaikan dengan kebutuhan siswa. Pemilihan warna juga dilakukan agar desain media E-Bookstory terlihat menarik sehingga siswa senang membacanya.

2. Membuat Rancangan Media E-Bookstory

Pada tahap merancangan media $E$ Bookstory ini, peneliti membuat sketsa yang nantinya akan menjadi isi dari setiap menu pilihan yang ada dalam E-Bookstory. Sketsa tersebut terdiri atas: a) rancangan tampilan pembuka, b) rancangan tampilan menu utama, c) rancangan tampilan menu pembuat, d) rancangan tampilan menu petunjuk, e) rancangan tampilan $\mathrm{KI} \& \mathrm{KD}, \mathrm{f})$ rancangan tampilan menu materi, $g$ ) rancangan tampilan menu evaluasi, h) rancangan tampilan menu komentar siswa, i) rancangan tampilan menu glosarium, j) rancangan tampilan menu daftar pustaka, k) rancangan tampilan menu ON/OFF suara, dan yang terakhir adalah rancangan tampilan, 1) konfirmasi keluar dari media E-Bookstory.

\section{B. Pengembangan Produk}

Tahap pengembangan produk merupakan prosedur kedua dalam penelitian dan pengembangan. Pada tahap ini produk yang sudah dirancang divalidasi oleh ahli pada bidangnya masing. Validasi dilakukan oleh pakar materi dan pakar media, dalam hal ini peneliti menggunakan tiga pakar dosen ahli, satu dosen pakar materi dan dua dosen pakar media. Pakar materi merupakan langkah untuk mengisi lembar validasi yang digunakan untuk menilai kesesuaian materi dan bahasa yang disajikan dalam media E-Bookstory. Uji validasi ahli materi juga dilakukan untuk menyempurnakan serta mengetahui kelebihan dan kelemahan secara konseptual menurut ahli materi.

Validasi pakar media merupakan validasi yang dilakukan oleh dosen ahli media, dengan mengisi lembar validasi untuk menilai kesesuaian media dari aspek tampilan, isi cerita E-Bookstory, bahasa, dan kepraktisan dalam penggunaan media. Setelah melakukan validasi peneliti akan merevisi produk sesuai dengan saran yang telah diberikan oleh pakar masing guna untuk menyempurnakan produk yang sudah dikembangkan. Teknik pengumpulan data yang dilakukan peneliti yaitu melalui uji pakar. Uji pakar yang digunakan adalah uji pakar materi dan uji pakar media. Uji pakar ini bertujuan untuk menilai keefektifan media yang dikembangkan, apakah layak untuk digunakan di $\mathrm{SD}$, lembar validasi diisi oleh pakar materi dan pakar media.

Data hasil validasi produk oleh pakar materi dan pakar media, akan dianalisis menggunakan teknik deskriptif persentase dan kategori untuk 
1011 Pengembangan Media Pembelajaran Berbasis E-Bookstory untuk Meningkatkan Literasi Membaca Siswa Sekolah Dasar - Desy Getri Sari Gogahu, Tego Prasetyo.

DOI: https://doi.org/10.31004/basicedu.v4i4.493

menunjukkan kelayakan media. Skor hasil pengukuran menggunakan angket tertutup, kemudian dipersentasekan menggunakan rumus berikut ini.

$$
\mathrm{AP}=\frac{\text { Skor Aktual }}{\text { Skor Ideal }} \times 100 \%
$$

Keterangan

$\mathrm{AP}=$ Angka Presentase

Skor Aktual $=$ Skor yang diberikan validator

Skor Ideal $=$ Skor maksimal hasil kali antara jumlah item dengan skor maksimal masing-masing item.

Angka persentase kemudian dikelompokkan menjadi lima kategori yang dapat dilihat pada tabel dibawah ini.

Tabel 1. Persentase Analisis Data

\begin{tabular}{|c|c|}
\hline Interval & Kategori \\
\hline $\mathbf{8 1 - 1 0 0 \%} \%$ & Sangat tinggi \\
\hline $\mathbf{6 1 - 8 0} \%$ & Tinggi \\
\hline $\mathbf{4 1 - 6 0 \%}$ & Cukup \\
\hline $\mathbf{2 1 - 4 0 \%}$ & Rendah \\
\hline $\mathbf{1 - 2 0 \%}$ & Sangat rendah \\
\hline
\end{tabular}

\section{HASIL DAN PEMBAHASAN}

\section{Hasil Studi Pendahuluan}

Berdasarkan hasil studi pendahuluan dapat diketahui pentingnya kebutuhan sekolah akan sebuah media untuk dapat menunjang kegiatan pembelajaran. Dari observasi yang dilakukan peneliti menemukan bahwa siswa suka membaca buku, hanya saja siswa cepat bosan karena cerita dan gambar buku kurang menarik, ada juga beberapa buku yang bahasanya terlalu tinggi sehingga isi bacaan sulit di pahami oleh siswa SD. Walaupun masalah tersebut telah disadari oleh guru, namun guru tidak sempat untuk melakukan pengembangan media yang dapat menanggulangi atau meminimalkan permasalahan tersebut. Guru hanya melakukan kegiatan pembelajaran dengan panduan buku dari rancangan pemerintah yang kondisi seharusnya guru mampu mengembangkan secara mandiri, serta guru masih memakai cara lama untuk pembelajaran khusus dalam literasi membaca.

Berdasarkan hasil survei yang mengatakan bahwa kurangnya literasi membaca siswa dalam pembelajaran yang kurang sesuai dengan kondisi nyata siswa, masalah tersebut menyebabkan siswa kurang memahami materi pembelajaran yang disampaikan oleh guru melalui literasi membaca. Proses pembelajaran literasi membaca seharusnya membuat siswa senang membaca isi bacaan tersebut, dengan demikian memudahkan siswa untuk memahami isi bacaan dari mater tersebut. Dengan melakukan pembelajaran menggunakan media E-Bookstory membaca lebih menyenangkan karena kalimat yang digunakan dalam materi tersebut menjadi lebih sederhana dan lebih mudah untuk di pahami siswa. Guru juga lebih mudah melakukan pembelajaran, karena guru yang mengetahui kondisi nyata yang terjadi pada siswa. Dengan demikian peneliti melakukan pengembangan media E-Bookstory ini menjadi suatu kebutuahan sekolah atau guru agar pembelajaran menjadi lebih menyenangkan.

\section{Hasil Pengembangan Media E-Bookstory}


1012 Pengembangan Media Pembelajaran Berbasis E-Bookstory untuk Meningkatkan Literasi Membaca Siswa Sekolah Dasar - Desy Getri Sari Gogahu, Tego Prasetyo.

DOI: https://doi.org/10.31004/basicedu.v4i4.493

Desain pengembangan media $E$ Bookstory adalah upaya perencanaan sebuah media yang menggunakan tematik untuk mengaitkan muatan pembelajaran Bahasa Indonesia dan IPA dengan materi yang disusun menjadi cerita nonfiksi yang sesuai dengan kehidupan sehari-hari sehingga mudah di pahami oleh siswa SD. Media E-Bookstory ini dirancang dalam bentuk buku cerita nonfiksi berbasis elektronik, yang dilengkapi dengan, Identitas Pembuat, Petunjuk, KI/KD, Isi Materi, Evaluasi, Komentar, Glosarium, dan Daftar Pustaka. Isi materi yang terdapat pada media $E$ Bookstory disesuaikan dengan buku guru dan buku siswa kelas $\mathrm{V}$ tentang Ekosistem. Perancangan media E-Bookstory dilakukan peneliti menggunakan aplikasi Construct dan didesain menggunakan aplikasi adobe ilustrator. Berikut ini salah satu gambar hasil desian dari media E-Bookstory.

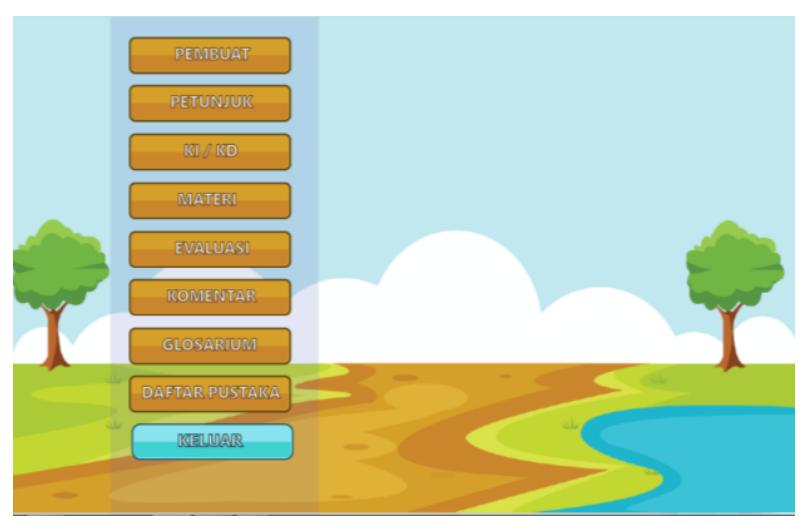

Gambar 2. Hasil Desain Tampilan Menu Utama.

Rancangan tampilan pada menu utama merupakan beberapa pilihan menu yang terdiri atas, Identitas Pembuat, Petunjuk, KI/KD, Isi Materi, Evaluasi, Komentar, Glosarium, Daftar
Pustaka, dan Tombol Keluar. Pada setiap menu pilihan ini terdapat tombol masing-masing yang berfungsi untuk menampilkan isi dari setiap menu pilihan yang ada. Produk hasil akhir pengembangan media ini berupa website yang dapat dibuka dengan link http://ebookstoryekosistem.com/.

\section{Validasi Produk E-Bookstory}

a. Hasil Validasi Pakar Materi

Validasi pakar materi dilakukan oleh dua dosen dari Pendidikan Guru Sekolah Dasar, Fakultas Keguruan dan Ilmu Pendidikan, Universitas Kristen Satya Wacana. Tujuan validasi oleh pakar materi adalah untuk menilai kesesuaian materi yang disajikan dan bahasa dalam media E-Bookstory. Selain itu, peneliti juga mengharapkan adanya kritik dan saran perbaikan dari pakar materi agar media $E$ Bookstory dapat dikembangkan sesuai dengan materi yang akan diajarkan. Setiap item pernyataan pada lembar validasi materi memiliki skor maksimal 5 dan skor minimum 1. Hasil validasi oleh pakar materi dapat di lihat pada tabel 2 berikut.

\section{Tabel 2. Hasil Validasi Pakar Materi}

\begin{tabular}{|c|c|c|}
\hline \begin{tabular}{l}
\multicolumn{1}{c}{ Aspek } \\
Materi \\
Pembelajaran
\end{tabular} & Indikator & Skor \\
\hline \multirow[t]{5}{*}{$\begin{array}{l}\text { Materi } \\
\text { Pembelajaran }\end{array}$} & $\begin{array}{l}\text { 1. Kesesuaian dengan KI } \\
\text { dan KD } 2013\end{array}$ & 4 \\
\hline & $\begin{array}{l}\text { 2. Kesesuaian antara } \\
\text { Indikator dengan } \mathrm{KD}\end{array}$ & 4 \\
\hline & $\begin{array}{l}\text { 3. Kesesuaian dengan } \\
\text { tujuan pembelajaran }\end{array}$ & 3 \\
\hline & $\begin{array}{l}\text { 4. Kesesuaian judul } \\
\text { dengan isi materi } \\
\text { pembelajaran }\end{array}$ & 5 \\
\hline & 5. Kelengkapan Materi & 5 \\
\hline
\end{tabular}


1013 Pengembangan Media Pembelajaran Berbasis E-Bookstory untuk Meningkatkan Literasi Membaca Siswa Sekolah Dasar - Desy Getri Sari Gogahu, Tego Prasetyo.

DOI: https://doi.org/10.31004/basicedu.v4i4.493

\begin{tabular}{|c|c|c|}
\hline & $\begin{array}{l}\text { 6. Kejelasan Bahasa yang } \\
\text { digunakan }\end{array}$ & 4 \\
\hline & $\begin{array}{l}\text { 7. Kejelasan isi cerita } \\
\text { dengan } \\
\text { pembelajaran }\end{array}$ & 4 \\
\hline & $\begin{array}{l}\text { 8. Kesesuaian ilustasi } \\
\text { cerita dengan materi } \\
\text { pembelajaran }\end{array}$ & 4 \\
\hline Bahasa & $\begin{array}{l}\text { 9. Keefektifan kalimat } \\
\text { (sederhana dan jelas) }\end{array}$ & 4 \\
\hline & 10. Kebakuan istilah & 4 \\
\hline & $\begin{array}{l}\text { 11. Tanda baca yang } \\
\text { digunakan sesuai dan } \\
\text { tepat }\end{array}$ & 4 \\
\hline & $\begin{array}{l}\text { 12. Kesesuaian dengan } \\
\text { tingkat perkembangan } \\
\text { emosional siswa }\end{array}$ & 4 \\
\hline Jumla & & 49 \\
\hline Presen & & $82 \%$ \\
\hline
\end{tabular}

Berdasarkan hasil evaluasi oleh pakar materi media E-Bookstory yang dikembangkan oleh peneliti mendapatkan skor 49 dengan presentase $82 \%$, sehingga dikategorikan sangat tinggi dan layak untuk digunakan.

\section{b. Hasil Validasi Pakar Media}

Validasi pakar media dilakukan oleh dua dosen. Dosen 1 dari Fakultas Teknologi dan Informasi, Universitas Kristen Satya Wacana, dan dosen 2 dari Pendidikan Guru Sekolah Dasar, Fakultas Keguruan dan Ilmu Pendidikan Universitas Kristen Satya Wacana. Tujuan validasi pakar media adalah untuk mengetahui kelayakan produk dari aspek tampilan, isi cerita nonfiksi, bahasa dan kepraktisan dalam penggunaan. Selain itu, peneliti juga mengharapkan kritik dan saran perbaikan dari pakar media agar media E-Bookstory yang dikembangkan layak untuk digunakan. Setiap item pernyataan pada lembar validasi media memiliki skor maksimal 5 dan skor minimum 1.
Hasil validasi oleh pakar media 1 dan 2 dapat dilihat pada tabel 3 dan tabel 4 berikut ini.

Tabel 3. Hasil Validasi Pakar Media 1

\begin{tabular}{|c|c|c|}
\hline Aspek & Indikator & Skor \\
\hline \multirow[t]{5}{*}{ Tampilan } & $\begin{array}{l}\text { 1. Kesesuaian jenis huruf } \\
\text { dan ukuran huruf yang } \\
\text { digunakan untuk kelas } \\
5 \text { SD }\end{array}$ & 3 \\
\hline & $\begin{array}{l}\text { 2. Kesesuaian ilustrasi } \\
\text { gambar dengan cerita }\end{array}$ & 4 \\
\hline & $\begin{array}{lr}\text { 3. Kesesuaian } & \text { dengan } \\
\text { pemilihan } & \text { latar } \\
\text { belakang } & \text { disetiap } \\
\text { halaman } & \end{array}$ & 4 \\
\hline & $\begin{array}{l}\text { 4. Kesesuaian teks dengan } \\
\text { warna }\end{array}$ & 2 \\
\hline & $\begin{array}{l}\text { 5. Ketepatan bentuk teks } \\
\text { dengan gambar }\end{array}$ & 2 \\
\hline \multirow[t]{3}{*}{ Isi Cerita } & $\begin{array}{lr}\text { 6. Kesesuaian } & \text { antara } \\
\text { media } & \text { E-Bookstory } \\
\text { dengan } & \text { materi } \\
\text { pembelajaran. } & \\
\end{array}$ & 4 \\
\hline & $\begin{array}{l}\text { 7. Kebermanfaatan media } \\
\text { buku cerita bergambar } \\
\text { dalam mempermudah } \\
\text { pemahaman konsep. }\end{array}$ & 4 \\
\hline & $\begin{array}{l}\text { 8. Kebermanfaatan buku } \\
\text { dalam meningkatkan } \\
\text { minat membaca siswa. }\end{array}$ & 4 \\
\hline \multirow[t]{3}{*}{ Bahasa } & $\begin{array}{l}\text { 9. Keefektifan kalimat } \\
\text { dalam media } E- \\
\text { Bookstory }\end{array}$ & 2 \\
\hline & 10. Kebakuan istilah & 3 \\
\hline & $\begin{array}{l}\text { 11. Kesesuaian dengan } \\
\text { tingkat } \\
\text { perkembangan } \\
\text { emosional siswa. }\end{array}$ & 4 \\
\hline \multirow{3}{*}{$\begin{array}{l}\text { Kepraktisan } \\
\text { dalam } \\
\text { penggunaan. }\end{array}$} & $\begin{array}{l}\text { 12. Kejelasan Petunjul } \\
\text { penggunaan media }\end{array}$ & 3 \\
\hline & $\begin{array}{l}\text { 13. Tingkat kemudahan } \\
\text { mengakses media E- } \\
\text { Bookstory }\end{array}$ & 4 \\
\hline & $\begin{array}{l}\text { 14. Tingkat kemudahan } \\
\text { penggunaan media }\end{array}$ & 4 \\
\hline \multicolumn{2}{|l|}{ Jumlah } & 47 \\
\hline \multicolumn{2}{|l|}{ Presentase } & $67 \%$ \\
\hline
\end{tabular}

Berdasarkan hasil evaluasi oleh pakar media

1, media E-Bookstory yang dikembangkan oleh 
1014 Pengembangan Media Pembelajaran Berbasis E-Bookstory untuk Meningkatkan Literasi Membaca Siswa Sekolah Dasar - Desy Getri Sari Gogahu, Tego Prasetyo.

DOI: https://doi.org/10.31004/basicedu.v4i4.493

peneliti mendapatkan skor 47 dengan presentase sebesar $67 \%$, sehingga dikategorikan tinggi dan layak untuk digunakan.

Tabel 4. Hasil Validasi Pakar Media 2

\begin{tabular}{|c|c|c|}
\hline Aspek & Indikator & Skor \\
\hline \multirow[t]{5}{*}{ Tampilan } & $\begin{array}{l}\text { Kesesuaian jenis huruf } \\
\text { dan ukuran huruf yang } \\
\text { digunakan untuk kelas } \\
5 \mathrm{SD}\end{array}$ & 3 \\
\hline & $\begin{array}{l}\text { 2. } \begin{array}{l}\text { Kesesuaian ilustrasi } \\
\text { gambar dengan cerita }\end{array}\end{array}$ & 3 \\
\hline & $\begin{array}{llr}\text { 3. } & \text { Kesesuaian } & \text { dengan } \\
\text { pemilihan } & \text { latar } \\
\text { belakang } & \text { di } & \text { setiap } \\
\text { halaman } & & \\
\end{array}$ & 3 \\
\hline & $\begin{array}{lll}\text { 4. } & \text { Kesesuaian } \\
\text { dengan warna } & \text { teks } \\
\end{array}$ & 3 \\
\hline & $\begin{array}{ll}\text { 5. } & \begin{array}{l}\text { Ketepatan bentuk teks } \\
\text { dengan gambar }\end{array}\end{array}$ & 3 \\
\hline \multirow[t]{3}{*}{ Isi Cerita } & 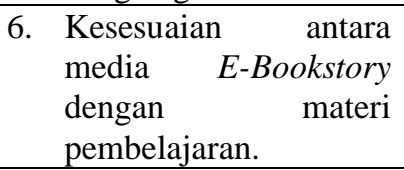 & 4 \\
\hline & $\begin{array}{l}\text { 7. Kebermanfaatan media } \\
\text { buku cerita bergambar } \\
\text { dalam mepermudah } \\
\text { pemahaman konsep. }\end{array}$ & 3 \\
\hline & $\begin{array}{l}\text { 8. Kebermanfaatan buku } \\
\text { dalam meningkatkan } \\
\text { minat membaca siswa. }\end{array}$ & 3 \\
\hline \multirow[t]{3}{*}{ Bahasa } & $\begin{array}{l}\text { 9. Keefektifan kalimat } \\
\text { dalam media E- } \\
\text { Bookstory }\end{array}$ & 3 \\
\hline & 10. Kebakuan istilah & 3 \\
\hline & $\begin{array}{l}\text { 11. Kesesuaian dengan } \\
\text { tingkat perkembangan } \\
\text { emosional siswa. }\end{array}$ & 3 \\
\hline \multirow{3}{*}{$\begin{array}{l}\text { Kepraktisan } \\
\text { dalam } \\
\text { penggunaan. }\end{array}$} & $\begin{array}{l}\text { 12. Kejelasan Petunjuk } \\
\text { penggunaan media }\end{array}$ & 3 \\
\hline & $\begin{array}{l}\text { 13. Tingkat } \\
\text { mengakses media } \\
\text { Bookstory }\end{array}$ & 3 \\
\hline & $\begin{array}{l}\text { 14. Tingkat kemudahan } \\
\text { penggunaan media }\end{array}$ & 3 \\
\hline \multicolumn{2}{|l|}{ Jumlah } & 43 \\
\hline \multicolumn{2}{|l|}{ Presentase } & $61 \%$ \\
\hline
\end{tabular}

Berdasarkan hasil evaluasi oleh pakar media 2, pengembangan media E-Bookstory yang di kembangkan oleh peneliti mendapatkan skor 43 dengan persentase sebesar $61 \%$, sehingga dikategorikan tinggi, dan layak untuk digunakan dalam proses pembelajaran.

\section{SIMPULAN}

Berdasarkan hasil pengembangan yang dilakukan dapat disimpulkan bahwa media pembelajarn berbasis E-Bookstory dapat dikatakan sangat efektif digunakan untuk meningkatkan literasi membaca siswa. Dibuktikan dari hasil validasi oleh tiga dosen ahli, 1 dosen ahli materi dan 2 dosen ahli media. Hasil validasi materi mendapatkan skor 49 dengan persentase $82 \%$, sehingga dikategorikan sangat tinggi dan layak untuk digunakan. Hal ini terlihat juga pada hasil validasi media 1 memperoleh skor 47 dengan persentase sebesar $67 \%$, dan hasil validasi media 2 memperoleh skor 43 dengan persentase sebesar $61 \%$, sehingga dikategorikan tinggi dan layak untuk digunakan.

Saran dari peneliti yang pertama bagi guru melalui penelitian ini, guru bisa menggunakan media pembelajaran E-Bookstory dalam pembelajaran literasi membaca, agar siswa mulai terbiasa dan suka membaca buku karena dilengkapi dengan teks bacaan dan gambar yang menarik. Saran yang kedua bagi peneliti lain diharapkan melalui penelitian ini dapat menjadi salah satu referensi namun apabila mengembangkan $E$ Bookstory yang sama akan lebih baik jika menggunakan model pembelajaran dalam kurikulum 2013, sehingga proses pembelajaran 
1015 Pengembangan Media Pembelajaran Berbasis E-Bookstory untuk Meningkatkan Literasi Membaca Siswa Sekolah Dasar - Desy Getri Sari Gogahu, Tego Prasetyo.

DOI: https://doi.org/10.31004/basicedu.v4i4.493

lebih terarah pada kebutuhan dan kemampuan siswa.

\section{DAFTAR PUSTAKA}

Adeel, K. \&. (2014). Literasi Buku Digital. LIBRIA, $8(2)$.

Agoestyowati, R. (2017). Tinjauan Pada Minat Literasi Anak-anak. Majalah Ilmiah Institut STIAMI.

Baleiro, R. (2011). Definition of Literary A Content Analysis of Literature Syllabuses and Interviews with Protuguese Lecturers of Literature. Journal of New Horizons in Education, (02-04), 17.

Dalman. (2013). Ketrampilan Membaca. Jakarta: Raja Garafido Persada.

Dizon. (2014). Pengaruh Penggunaan Buku Bacaan Digital serta Kegiatan Membaca Digital, Terhadap Motivasi Membaca Siswa di Sekolah Dasar. Metodik Didaktik, 9(2).

Haris, D. (2011). Panduan Lengkap E-Book. Yogyakarta: Cakrawala.

Lopes-Rio. (2015). About the horrific peril of reading on digital devices. Journal of Social and Behavioral Sciiences, 178.

Peraturan Menteri Pendidikan dan Kebudayaan Nomor 23 Tahun 2015 tentang Penumbuhan Budi Pekerti. (n.d.).

Rusman Dr M, P. (2012). Belajar dan Pembelajaran Berbasis Komputer. Bandung: ALFABETA.

Sanjaya, W. (2012). Media Komunikasi Pembelajaran. Jakarta: Fajar Interpratama Mandiri.

Shofaussamawati. (2016). Menumbuhkan minat baca dengan pengenalan perpustakaan pada anak sejak dini. Journal Stainkudus. Retrieved fromhttp://journal.stainkudus.ac.id/index.p hp/Libraria/article/download/1189/1082

Smeets, D. J. . and A. G. B. (2012). Buku Cerita Elektronik Interaktif untuk Anak TK Mengenal Kosa Kata.
Sukmadinata, N. S. (2017). Metode Penelitian Pendidikan. Bandung: Remaja Rosdakarya.

Suyono, H. (2017). Implementasi Gerakan Literasi Guru Sekolah Pada Pembelajaran Tematik Sekolah Dasar. Jurnal Sekolah Dasar, 116123.

Tim, S. G. (2018). Buku Panduan Praktis Gerakan Literasi Sekolah. Jakarta: Kemdikbud Direektorat Jendral Pendidikan Dasar dan Menengah.

Undang-undang No.3 Tahun 2017 tentang Sistem Perbukuan. (n.d.).

UNESCO. (2009). Laporan Dunia UNESCO Berinvestasi dalam Keanekaragaman Budaya dan Dialog Antarbudaya. Tersedia di://www.unesco.org/en/world reports/cultural-diversity. Diakses 13 September 2019.

Yaumi, M. (2012). Prinsip-Prinsip Desain Pembelajaran. Jakarta: PT Interpratama Mandiri. 